Revista do SELL

v. 6 , no. 2

ISSN: $1983-3873$

\title{
A IDENTIDADE PÓS-MODERNA FIGURADA NO VISCONDE PARTIDO AO MEIO, DE ITALO CALVINO
}

THE POST-MODERN IDENTITY DEPICTED IN THE CLOVEN VISCOUNT, BY

ITALO CALVINO

\author{
Helen Cristine Alves Rocha \\ Universidade Federal de Uberlândia
}

\begin{abstract}
RESUMO: Sabemos que hoje o indivíduo é visto como constituído de várias identidades e não mais com uma identidade única. Por isso, este trabalho tem como objetivo fazer uma leitura da identidade pós-moderna a partir do espaço-corpo do Visconde, presente em $O$ visconde partido ao meio, de Italo Calvino. O Visconde foi partido ao meio por uma bala de canhão e suas metades passaram a viver separadas: uma tornou-se completamente maléfica e a outra insuportavelmente boa. O corpo do Visconde foi fragmentado, e a dicotomia entre bem e mal mostra que sua antiga identidade não era constituída apenas com uma forma de ser, mas a mistura que a compunha era o bem e o mal. Portanto, para cumprir com o objetivo proposto, tomaremos como fundamentação teórica obras que tratam da especificidade da literatura fantástica, elegendo os estudos de Filipe Furtado (1980, 2015), David Roas (2001) e Lenira Marques Covizzi (1978). Para os estudos sobre a identidade cultural na pós-modernidade elencamos Eurídice Figueiredo (2015), José Gil (2009) e Stuart Hall (2006). Dentro dos estudos sobre o medo teremos o auxílio de Maria Isabel Limongi (2007), Zygmunt Bauman (2008), Nathalie Frogneux (2007) e Maria Rita Kehl (2007).
\end{abstract}

PALAVRAS-CHAVE: Identidade pós-moderna; espaço-corpo; insólito; medo; Visconde.

ABSTRACT: Nowadays it is known that a person is seen as constituted by various identities, not by a unique one. For this reason, this work has the main goal of reading the post-modern identity critically from the space-body of the Viscount, which is in the book The Cloven Viscout, by Italo Calvino. The Viscount was split in two by a cannonball and those two parts started living separately: the former became completely bad and the latter, unbearably good. By the splitting of the Viscount, it is possible to think about the dichotomy between the good and the evil and the fact that his past identity was not only constituted by a way of being, but its mixture was both good and evil at the same time. Therefore, for achieving our goal, we take some authors for our theoretical assumptions: about the fantastic literature, Filipe Furtado (1980, 2015), David Roas (2001) and Lenira Marques Covizzi (1978); about cultural identity in post-modernity: Eurídice Figueiredo (2015), José Gil (2009) and Stuart Hall (2006); and about the studies of fear, Maria Isabel Limongi (2007), Zygmunt Bauman (2000), Nathalie Frogneux (2007) and Maria Rita Kehl (2007).

KEYWORDS: Post-modern identity; space-body; fantastic; fear; Viscount. 


\section{Revista do SELL}

v. 6 , no. 2

ISSN: $1983-3873$

\section{Introdução}

"Cada vez que o reino do humano me parece condenado ao peso, digo para mim mesmo que à maneira de Perseu eu devia voar para outro espaço" (CALVINO, 1990, p. 19).

Podemos pensar que a literatura, e as artes em geral, é uma forma de representação do homem e do mundo e, por isso, ela se configura como sendo um produto que está sempre em acabamento. Analogamente, a identidade também é uma forma de representação do homem e do lugar onde ele vive. Por isso, ela também é uma construção humana que nunca está pronta e acabada, mas em constante construção. Quando pensamos em identidade, estamos imaginando um "eu" que tem a possibilidade de adquirir e se identificar com vários traços culturais ao mesmo tempo. Ter uma identidade em devir. A questão da identidade não é simples, ela tem sido bastante discutida e difundida na teoria social. Assim, numa tentativa de definição da identidade do indivíduo português, José Gil (2009, p. 10) aponta que a identidade seria "o surgir do rosto do eu, como condição de possibilidade de afirmação de todos os atributos 'mundanos' do indivíduo, da afirmação deste como sujeito, antes do surgimento da singularidade do indivíduo como homem, ser nu em devir". Percebemos que o "eu" tem a possibilidade de escolha dos atributos que lhe convém, a partir, claro, de sua condição de acesso a eles. Esta é uma forma dele se reconhecer como um sujeito possuidor de identidades.

Devemos ter em mente que as pessoas já nascem inseridas em uma cultura, em um modo de vida comum e, desta maneira, sua identidade vai sendo construída e moldada de acordo com os valores e os costumes do lugar em que ela nasceu. Por outro lado, nada a impede de possuir várias identidades ao mesmo tempo. Como versa José Gil (2009, p. 10), na fala, na ação, nas relações sociais, na vida profissional, no espaço público, enfim, em tudo, nós somos "fulanos de tal", "somos pessoais e auto-reflexivos (o contrário da criança ou do artista ou artesão, perdidos no objecto e no jogo)". Somos criadores e possuidores de identidades a cada momento e situação de nossa vida.

As identidades que, supostamente, estabilizaram o mundo social, agora estão sendo repensadas e discutidas com mais ênfase, fazendo com que o indivíduo passe a ser visto como constituído de várias identidades e não mais com uma identidade única e uniforme. Os quadros de referências estáveis estão sendo abalados e os indivíduos podem tomar consciência de si como sujeitos produtores e possuidores de identidades. Não há mais uma ideia generalizada de identidade social. Para Stuart Hall (2006, p. 1), o 


\section{Revista do SELL}

v. 6 , no. 2

ISSN: $1983-3873$

argumento é que "as velhas identidades, que por tanto tempo estabilizaram o mundo social, estão em declínio, fazendo surgir novas identidades e fragmentando o indivíduo moderno", até então visto como um sujeito unificado. Para o autor, a crise da identidade é vista como parte de um processo mais amplo de mudança, "que está deslocando as estruturas e processos centrais das sociedades modernas e abalando os quadros de referência que davam aos indivíduos uma ancoragem estável no mundo social" (idem).

A partir dessas considerações, este artigo tem como objetivo abordar a questão da identidade pós-moderna, a qual está sendo vista como descentrada, deslocada e em constante construção, fazendo essa leitura a partir do protagonista de Italo Calvino, 0 Visconde, presente no livro $O$ visconde partido ao meio. Para tal fim, é importante frisar o motivo de ser o Visconde uma representação da identidade pós-moderna: ele foi partido ao meio por uma bala de canhão e seu espaço-corpo ${ }^{1}$ foi separado em duas partes, tornando-se uma completamente maléfica e outra insuportavelmente boa. Sua personalidade e sua configuração corpórea são fragmentadas.

Por tudo já arrolado, a execução deste trabalho se justifica pela ausência de trabalhos mais consistentes sobre a questão da identidade cultural pós-moderna a partir da obra de Calvino; e também pela tendência da narrativa fantástica de poder levar o homem a conhecer a si e ao mundo em que vive, oferecendo-lhe outro modo de olhar para as diferenças que existem em sua realidade imediata. Além disso, é uma narrativa divertida que mescla aventura, leveza e humor, e trata com ironia uma das facetas da pós-modernidade, na qual o homem se sente incompleto, buscando sempre sua satisfação, uma identidade estável, mas nunca é capaz de viver a plenitude de seus desejos nem mesmo de unificar sua identidade, andando desnudo por uma biblioteca pronta para derrubar-se (ACHUGAR, 1994, p. 23), mas em constante reconstrução.

Para Achugar (1994, p. 19), nossa biblioteca (conhecimento de mundo e de vivências) está em constante transformação, não só através dos meios de comunicação, mas por tudo aquilo que estamos aprendendo diariamente. "A leitura crítica não tem conseguido escapar da biblioteca e a leitura crítica desde o cotidiano - talvez até mesmo

\footnotetext{
1 "Espaço-corpo" é o termo que utilizamos para caracterizar o tema e o espaço que pretendemos analisar: o insólito no espaço do corpo do Visconde, de Italo Calvino. É importante ressaltar que, na década de 1950, o autor publicou a trilogia fantástica que o deixaria famoso internacionalmente: $O$ visconde partido ao meio, de 1952, O barão nas árvores, de 1957, e O cavaleiro inexistente, de 1959.
} 


\section{Revista do SELL}

v. 6 , no. 2

ISSN: $1983-3873$

uma transgressão subversiva - não sua anulação (ACHUGAR, 1994, p. 19)2". Isto também mostra que nossa identidade também está em constante transformação a partir das escolhas e da leitura que fazemos em nosso cotidiano. Por conseguinte, propomos mostrar como a identidade pós-moderna está manifesta no espaço-corpo e na conduta do Visconde, de Italo Calvino. É importante ressaltar que este autor é um dos mais importantes escritores italianos do século $X X$, consagrado pela tradição literária. Além disso, ele soube contribuir com a forma de refletir sobre o mundo e a pós-modernidade não só por meio dos seus ensaios, mas também através de seus personagens insólitos.

\section{O Visconde e a identidade pós-moderna}

Segundo Stuart Hall (2006), as sociedades modernas do fim do século XX estão sendo transformadas por um tipo diferente de mudança estrutural. Isso está fragmentando as paisagens culturais de gênero, classe, etnia, sexualidade, raça e nacionalidade, que, no passado, nos localizavam solidamente como indivíduos sociais. Essas transformações também têm mudado nossas identidades pessoais, abalando a ideia que temos sobre sermos sujeitos unificados, integrados. "Esta perda de um 'sentido de si' estável é chamada, algumas vezes, de deslocamento ou descentração do sujeito" (p. 1). Para Hall (2006), esse deslocamento - descentração do sujeito de seu lugar no mundo social e cultural quanto de si mesmo -, se configura como sendo uma "crise de identidade".

Para Kobena Mercer (apud HALL, 2006, p. 1), "a identidade somente se torna uma questão quando está em crise, quando algo que se supõe como fixo, coerente e estável é deslocado pela experiência da dúvida e da incerteza". O Visconde tinha uma identidade supostamente fixa, coerente e estável, mas foi partido ao meio por uma bala de canhão e, com isso, sua identidade se tornou uma questão por estar em crise. Ao mesmo tempo em que ele era uma só pessoa, com seu espaço-corpo dividido ao meio, ele também era duas pessoas com condutas diferentes. Destarte, o objetivo de nossa reflexão é mostrar como a identidade pós-moderna é representada pela conduta e pela configuração corpórea do protagonista da obra $O$ visconde partido ao meio, de Italo Calvino.

2 La lectura crítica no ha logrado escapar de la biblioteca y la lectura crítica desde lo cotidiano implica una alteración de la biblioteca - quizás hasta una subversiva transgresión - no su anulación" (ACHUGAR, 1994, p. 19 , tradução minha). 


\title{
Revista do SELL
}

v. 6 , no. 2

ISSN: $1983-3873$

A "crise de identidade" é encontrada no Visconde uma vez que o corpo e o caráter deste personagem tornam-se fragmentados e, portanto, ele excede nosso entendimento racional por ter o seu corpo dividido em duas metades que são independentes e opostas. Todavia, por outro lado, são partes de um só corpo que têm em comum o ódio dos outros personagens da obra, já que uma é completamente maléfica e a outra muito bondosa.

\begin{abstract}
Meu tio teve a ideia dos incêndios. Durante a noite, de repente, ardia um celeiro de camponeses miseráveis ou uma árvore boa para lenha ou então um bosque inteiro. Aí ficávamos até de manhã passando baldes d'água de mão em mão para apagar as chamas. As vítimas eram sempre pobres que tinham discutido com o visconde por causa de alguma de suas sentenças cada vez mais severas e injustas ou de tributos que havia duplicado. Não satisfeito de incendiar os bens, começou a pôr fogo nas casas: parecia que se aproximava à noite e depois escapava a cavalo; mas nunca ninguém conseguia apanhá-lo em flagrante. Certa vez morreram dois velhos; depois, um rapaz ficou com o crânio esfolado. Crescia entre os camponeses o ódio contra ele (CALVINO, 2011, p. 38).
\end{abstract}

O visconde colocava fogo em celeiros, em casas, em árvores boas para lenha ou até num bosque inteiro. Às vezes, os leprosos eram mortos porque não sentiam a casa incendiando. Ele sempre escapava, ninguém nunca conseguiu pegá-lo em flagrante. Quanto mais a parte má do visconde prejudicava as pessoas, mais elas sentiam ódio dele. Por sua vez, a parte boa também tornou-se insuportável:

As intenções do meu tio iam mais longe: não se propusera apenas a curar os corpos dos leprosos, mas também suas almas. E andava sempre entre eles pregando moral, metendo 0 nariz nos negócios deles, escandalizando-se e fazendo sermões. Os leprosos não o suportavam. Os tempos beatos e licenciosos do Prado do Cogumelo tinham acabado. Com aquela exígua figura rígida numa perna só, vestida de negro, cerimoniosa e distribuindo regras, ninguém podia fazer o que the apetecia sem ser recriminado em praça pública, suscitando malignidade e despeito. Até a música, à força de ouvi-la ser recriminada como fútil, lasciva e não inspirada em bons sentimentos, acabou provocando aversão, e os estranhos instrumentos deles se cobriram de pó. As mulheres leprosas, sem o desafogo das farras, viram-se de repente sozinhas diante da doença, e passavam as noites chorando e se desesperando (idem, p. 8586).

Nota-se que ambas as partes do visconde eram desagradáveis. Diante deste protagonista podemos experimentar sensações como de perplexidade, medo e confusão, pois ele é um ser que nunca vimos, do qual não ouvimos falar sobre e, portanto, que foge ao que estamos acostumados e à significação racional humana. Sua parte boa não só dava presentes aos pobres ou ajudava a curar os animais que sofreram algum ataque da 


\section{Revista do SELL}

v. 6 , no. 2

ISSN: $1983-3873$

outra meia parte, ela também era insuportável por tentar impor um modo de vida correto e perfeito, ao seu ver; por pregar a moral; intrometer nos negócios e fazer sermões ao povo de Terralba, município em que morava. Ela se metia até mesmo no gosto particular das pessoas, pois criticava as músicas que se ouvia como não sendo inspiradas em bons sentimentos, fazendo com que as pessoas parassem tanto de tocar como de ouvir as músicas que gostavam. Ela proibia as mulheres leprosas de saírem de casa. As pessoas eram obrigadas a cumprir com sua vontade, pois ela era o visconde.

Ao longo do tempo, as pessoas foram acumulando ressentimentos de ambas as partes do visconde. Metades que estavam cada dia mais detestáveis. As pessoas comentavam: "- Das duas metades a boa é pior que a mesquinha" (CALVINO, 2011, p. 86). A admiração que elas tinham pelo Bom começava a diluir-se. "- Ainda bem que a bala do canhão só o dividiu em dois - diziam todos -, se o cortasse em três quem sabe o que nos tocaria ver pela frente" (idem). Não havia somente os turnos dos huguenotes, moradores da região, para se protegerem da metade má, agora também se protegiam da metade boa. "Assim passavam os dias em Terralba, e os nossos sentimentos se tornavam incolores e obtusos, pois nos sentíamos como perdidos entre maldades e virtudes igualmente desumanas" (CALVINO, 2011, p. 86).

$\mathrm{Na}$ obra, aquilo que nos deixa confusos tem a feição do insólito, ou seja, trata-se de algo que vem corroer uma "normalidade" e uma verossimilhança que nada parecia capaz de abalar: o feitio da vida do visconde parece incompatível, pois ele foi partido ao meio e, mesmo assim, vive como qualquer outro personagem da obra. Assim sendo, o Visconde é o personagem insólito da obra, já que o termo insólito é empregado dentro da literatura fantástica como sendo seu elemento mais importante. Ele é aquilo "que carrega consigo e desperta no leitor, o sentimento do inverossímil, incômodo, infame, incongruente, impossível, infinito, incorrigível, incrível, inaudito, inusitado, informal" (COVIZZI, 1978, p. 26, grifos da autora). O insólito, como reforça a autora, não se transforma em rotina, porque não permite o padrão, mas seu contrário: é tudo aquilo que quebra com nosso real. A autora aproxima-se da tese de Filipe Furtado (1980), o qual também acredita que a irrupção do fantástico se dá a partir de um elemento ou evento sobrenatural. Essa literatura do sobrenatural abrigaria o fantástico, o maravilhoso e o estranho, sendo caracterizada por abrigar "temas que traduzem uma fenomenologia meta-empírica” (p. 20, grifo do autor). Com o qualificativo meta-empírico, Furtado (1980, p. 20) pretende 


\section{Revista do SELL}

v. 6 , no. 2

ISSN: $1983-3873$

significar que a fenomenologia assim referida está para além do que é verificável ou cognoscível a partir da experiência, tanto por intermédio dos sentidos ou das potencialidades cognitivas da mente humana, como através de quaisquer aparelhos que auxiliem, desenvolvam ou supram essas faculdades.

Portanto, para o autor, a fenomenologia meta-empírica inclui qualquer tipo de fenômenos sobrenaturais na concepção mais corrente do termo, como aqueles que, tendo existência objetiva, fariam parte de um sistema de natureza diferente do universo conhecido, e também todos os que, "seguindo embora os princípios ordenadores do mundo real, são considerados inexplicáveis e alheios a ele apenas devido a erros de percepção ou desconhecimento desses princípios por parte de quem porventura os testemunhe" (FURTADO, 1980, p. 20). Logo, tanto os fenômenos sobrenaturais explicáveis racionalmente como os que são considerados desconhecidos estão dentro do conjunto de manifestações designado de meta-empírico, o qual se relaciona à realidade $\mathrm{e}$ está além do que podemos verificar em nosso cotidiano. Um fenômeno que não pode ter sido objeto da experiência. Entendemos, então, que a literatura fantástica está além do que é explicável, do empírico, da própria experiência humana.

Italo Calvino, participando de uma enquete sobre a literatura fantástica, em 15 de agosto de 1970, para a revista Le Monde, por ocasião do lançamento do livro Introduction à la littérature fantastique, de Tzvetan Todorov, responde a uma pergunta sobre a definição de fantástico apontando que, na linguagem francesa, o termo fantástico era utilizado sobretudo para as histórias que causavam espanto e implicavam uma relação com o leitor à moda oitocentistas: "o leitor (se quiser participar do jogo, pelo menos com uma parte de si) tem de acreditar naquilo que lê, aceitar ser apanhado por uma emoção quase fisiológica (costumeiramente, de terror, ou de angústia) e procurar uma explicação, como para uma experiência de vida" (CALVINO, 2006, p. 256, grifo do autor). Portanto, caso o leitor tenha o desejo de participar do jogo proposto pela narrativa, ele deve tomar 0 mundo ali proposto como verdadeiro e aceitar ser resgatado por ele, podendo se sentir como parte da própria narrativa. Por outro lado, Calvino versa que em italiano, como também deve ser originariamente em francês, os termos fantasia e fantástico

não implicam absolutamente esse mergulho do leitor na corrente emocional do texto; implicam, ao contrário, uma tomada de distância, uma levitação, a aceitação de uma lógica outra que leva para objetos outros e nexos outros, diversos daqueles da experiência diária (ou das convenções literárias dominantes). Desse modo, podemos falar de fantástico no século 


\section{Revista do SELL}

v. 6 , no. 2

ISSN: $1983-3873$

XX ou então de fantástico no Renascimento. Para os leitores de Ariosto, nunca se impôs o problema de acreditar ou de explicar, para eles, como hoje para os leitores de $O$ nariz de Gogol, de Alice no País das Maravilhas, da Metamorfose de Kafka, o prazer do fantástico está no desenvolvimento de uma lógica cujas regras, cujos pontos de partida ou cujas soluções reservam surpresas (CALVINO, 2006, p. 265-267, grifo do autor).

Italo Calvino (2006) está entre os que propõem e ampliam a definição de fantástico, não considerando que a literatura fantástica esteja reduzida aos séculos XVIII e XIX, como considera Todorov, mas que se mantenha nos séculos XX e XXI adentro. $O$ leitor, nesse sentido, tomando distância do texto, abre-se a surpresas com enredos que o capturam e o levam a outras realidades. A aceitação de uma lógica outra que leva para objetos e nexos que ainda não conhecíamos em nossa experiência cotidiana e nem mesmo nas convenções literárias dominantes: o insólito. A literatura fantástica pode até desprender o sujeito de seu real e desencadear sua imaginação, mas, principalmente, como na obra que estamos analisando, ela pode propiciar uma leitura da sociedade em que vivemos, fazendo-nos refletir sobre o que nos torna humanos.

David Roas (2001) ressalta que a maioria dos críticos coincide em assinalar que a condição indispensável para que se produza o efeito fantástico é a presença de um fenômeno sobrenatural (p. 7-8). O termo sobrenatural que o autor utiliza liga-se a uma clara significação religiosa, ou seja, refere-se à intervenção de forças de origem demiúrgica, angelical e/ou demoníaca. Ele designa a tudo aquilo que transcende a realidade humana. O elemento sobrenatural é uma condição cine qua non para a existência do fantástico tanto gênero como modo. "O sobrenatural é aquilo que transgredi as leis que organizam o mundo real, aquilo que não é explicável, que não existe, segundo ditas leis" (ROAS, 2001, p. 8) ${ }^{3}$. Destarte, percebemos, novamente, que a literatura fantástica está em relação com nosso real transgredindo-o ao fazer surgir em seu meio acontecimentos impossíveis, os quais não possuem uma explicação racional. Temos, portanto, um visconde que, durante a guerra, foi fendido ao meio:

Entusiasta e inexperiente, não sabia que só podemos nos aproximar de canhões lateralmente ou do lado da culatra. Saltou na frente da boca de fogo, de espada em punho, e imaginava assustar os dois astrônomos. Ao contrário, mandaram-lhe um canhonaço em pleno peito. Medardo de Terralba saltou pelos ares. [...] Erguido o lençol, o corpo do visconde mostrou-se terrivelmente mutilado. Faltava-Ihe um braço e uma perna, e

\footnotetext{
3 "es el único género literário que no puede funcionar sin la presencia de lo sobrenatural. Y lo sobrenatural es aquello que transgrede las leyes que organizan el mundo real, aquello que no es explicable, que no existe, según dichas leyes" (ROAS, 2001, p. 8, tradução minha).
} 


\section{Revista do SELL}

v. 6 , no. 2

ISSN: $1983-3873$

não só, tudo o que havia de tórax e abdômen entre aquele braço e aquela perna, fora arrancado, pulverizado pelo canhonaço recebido em cheio (CALVINO, 2011, p. 19-20).

O Visconde era um soldado perfeito fisicamente, no sentido de ter os dois braços, as duas pernas e os dois olhos juntos em um mesmo corpo. Entretanto, era inexperiente e, por isso, acabou sendo separado ao meio por uma bala de canhão. Ele estava terrivelmente mutilado, e o que nos causa mais espanto é o fato de lhe faltar um braço, uma perna, e tudo o que tinha de tórax e abdômen ter sido arrancado, partido e pulverizado pela bala de canhão. Similarmente à nossa realidade, sabemos que é totalmente impossível a existência de um ser tão extraordinário como este. O ser humano só tem uma boa saúde, um bom condicionamento físico se tiver nutrido de todas as partes de seu corpo e se elas estiverem em ótimo funcionamento.

Italo Calvino criou um espaço similar à realidade do leitor da obra, um espaço que se verá assaltado por um fenômeno que, de alguma forma, transtornará sua estabilidade (ROAS, 2001, p. 8). Esse espaço é onde se encontra o sobrenatural, aquilo que desestabiliza o leitor por não fazer parte de sua realidade cotidiana: o corpo de Medardo foi mutilado e isso não o matou. As metades de seu corpo foram costuradas separadamente e voltaram para seu castelo como se nada tivesse acontecido. Portanto, percebe-se que o personagem principal é um ser insólito, incomum.

Da cabeça sobravam um olho, uma orelha, uma bochecha, meio nariz, meia boca, meio queixo e meia testa: da outra metade só restava um mingau. Em suma, salvara-se apenas metade, a parte direita, que aliás se conservara perfeitamente, sem nem sequer um arranhão, excluindo aquela enorme rasgadura que separara da parte esquerda estraçalhada (CALVINO, 2011, p. 20).

Perante o Visconde podemos ficar perplexos e confusos já que ele é um ser que nunca vimos, do qual não ouvimos falar sobre e que foge à significação racional humana. Há a invasão do sobrenatural e sua condição de inexplicável até o fim da narrativa. Portanto, estamos diante de uma narrativa do gênero fantástico e, por outro lado, do gênero maravilhoso, porque não há explicação natural nem sobrenatural para um homem que tem as metades de seu corpo vivendo separadas. Um mundo autônomo no qual todos os acontecimentos são possíveis e naturais. Em contrapartida, também estamos dentro do que Furtado (2015) considera como fantástico modo: 


\section{Revista do SELL}

v. 6 , no. 2

ISSN: $1983-3873$

Trata-se, afinal, do único factor que, a despeito da sua índole extra-literária é comum a todos: o conceito geralmente designado por sobrenatural. [...] De facto, no seu sentido mais comum e mais lato, deixa subentender que as entidades ou ocorrências por ela qualificadas ultrapassam a natureza conhecida, situando-se, de algum modo, num plano simultaneamente exterior e superior. Por outro lado, o vocábulo tem servido ao longo de eras para referir uma multidão heterogênea de elementos, desde as fadas, os espectros ou as divindades das diversas religiões aos casos de percepção extra-sensorial e as figuras monstruosas de lendas populares como 0 lobisomem ou o vampiro (FURTADO, 2015, p. 1).

O autor aproxima-se da tese de David Roas (2001), para quem a definição de fantástico inclui as narrativas em que o sobrenatural não é colocado em discussão. Desse modo, entendemos que para Furtado (2015) a irrupção do fantástico se dá a partir de um elemento ou evento sobrenatural, isto é, através de um elemento insólito, que também podemos denominar como sendo o real da obra. Essa definição se refere a coisas que ultrapassam aquilo que conhecemos na realidade, elementos que se situam em um plano exterior e superior, do qual nada sabemos nem conhecemos. Percebemos que os termos insólito, sobrenatural e meta-empírico aludem a algo que esteja no plano do desconhecido, não no da nossa experiência ordinária. De modo igual, o termo se refere a Medardo devido ao fato de ele ter sido fendido ao meio e as metades de seu corpo viverem atuantes dentro da sociedade. Temos um acontecimento que está além daquilo que habitualmente conhecemos. Além de vermos um corpo pela metade, percebemos metades opostas: uma dicotomia entre bem e mal. Não só o espaço-corpo do visconde sofreu alterações, mas sua forma de ser e agir também mudou.

Atualmente, fala-se em identidade cultural pensando na existência do sujeito em meio ao conjunto cultural, meio no qual ele vive. Stuart Hall (2006) distingue três concepções de identidade: a do sujeito do lluminismo; a do sujeito sociológico; e, por fim, a do sujeito pós-moderno. Todas se relacionam com o Visconde de Italo Calvino, mesmo porque quando escrevemos criamos identidades. A primeira concepção de identidade está baseada numa concepção "da pessoa humana como um indivíduo totalmente centrado, unificado, dotado das capacidades de razão, de consciência e de ação, cujo 'centro' consistia num núcleo interior" (HALL, 2006, p. 2), o qual nascia e se desenvolvia com o sujeito, permanecendo o mesmo ao longo de sua existência.

O centro do "eu" era sua identidade. Isso ocorre com o Visconde, pois antes de ser partido ao meio ele era considerado um sujeito que possuía a capacidade de razão, consciência e ação, um soldado de guerra que lutava pela vitória de seu país e agia como 


\section{Revista do SELL}

v. 6 , no. 2

ISSN: $1983-3873$

qualquer outro militante: "Meu tio acabava de chegar, se alistara havia pouco, para agradar a alguns duques, nossos vizinhos, empenhados naquela guerra. Munira-se de um cavalo e um escudeiro no último castelo em mãos cristãs, e ia apresentar-se ao quartel imperial" (CALVINO, 2011, p. 11). Medardo era um visconde que não tinha experiência na guerra. Estava ali apenas por curiosidade e para agradar alguns duques que eram seus vizinhos. O narrador, seu sobrinho, conta que seu tio se achava na primeira juventude: "a idade em que os sentimentos se misturam todos num ímpeto confuso, ainda não separados em bem e mal; a idade em que cada experiência nova, também macabra e desumana, é toda trepidante e efervescente de amor pela vida" (idem, p.11-12). Sua identidade se encontrava na época de entusiasmo, de vontade de conquistas e mudanças; estava misturada, como que unificada em uma mesma aspiração.

\footnotetext{
"Uh, que maravilha de caso!" Se não morresse logo, até podiam tentar salvá-lo. E todos o rodearam, enquanto os pobres soldados com uma flecha no braço morriam de septicemia. Costuraram, adaptaram, amassaram: sabe-se lá o que fizeram. O resultado foi que no dia seguinte meu tio abriu o único olho, a meia-boca, dilatou a narina e respirou. A dura fibra dos Terralba resistira. Agora estava vivo e partido ao meio (CALVINO, 2011, p. 20).
}

O visconde mostra o absoluto da passagem, a instabilidade. Seu espaço-corpo não está delimitado, mas pode transformar-se novamente. Os médicos ficaram empolgados com aquele caso raro e esquisito. Eles até acreditaram que o visconde não sobreviveria, mas acabaram costurando, remendando aquela meia parte de Medardo. No dia seguinte, como numa espécie de milagre, o visconde dilatou a narina e respirou; é como se tivesse ressuscitado. Estava vivo e fendido ao meio. Não costuraram "suas metades", mas partes fragmentadas de seu corpo. Por isso, a primeira, a má, volta para Terralba e depois de um tempo a segunda metade também retorna. Os outros personagens se impressionaram com a primeira metade do Visconde, mas logo se acostumaram e agiram como se nada tivesse acontecido e ele fosse inteiro. "Meu tio, contrariado por ter provocado tamanha impressão em nós, avançou a ponta da muleta no chão e com um movimento comedido dirigiu-se para a entrada do castelo" (CALVINO, 2011, p. 23). Os médicos conseguiram juntar uma matéria para formar um quase-corpo 


\section{Revista do SELL}

v. 6 , no. 2

ISSN: $1983-3873$

humano. A hesitação ${ }^{4}$ provocada nos personagens logo se desfaz, pois é o gênero maravilhoso e o fantástico modo que se instalam.

Quando volta para Terralba, a metade boa do visconde conta para Pamela, moça por quem vai se apaixonar, a verdadeira história do que aconteceu na guerra: não era verdade que a bala de canhão havia esmagado a parte esquerda de seu corpo, mas ele foi dividido em duas metades; uma foi encontrara pelos catadores de feridos do exército e a outra não foi vista porque ficou enterrada sob uma pirâmide de restos cristãos e turcos.

No coração da noite passaram pelo campo dois eremitas, não se sabe bem se fiéis à religião justa ou nigromantes, os quais, como acontece com alguns nas guerras, acabaram vivendo nas terras desertas entre os dois campos e talvez, agora se comenta, tentassem abraçar juntas a Trindade cristã e o Alá de Maomé. Em sua piedade bizzarra, os eremitas, tendo encontrado o corpo dividido de Medardo, levaram-no para sua espelunca e ali, com bálsamos e unguentos por eles preparados, tinham-no medicado e salvado. Assim que recuperou as forças, o ferido despedira-se dos salvadores e, andando com sua muleta, percorrera durante meses e anos as nações cristãs para voltar ao seu castelo, maravilhando as pessoas ao longo do caminho com seus atos de bondade (CALVINO, 2011, p. 70).

Ironicamente, e talvez relacionado à educação laica de Calvino, o narrador fala que os eremitas, em sua piedade bizzara, levaram o corpo dividido de Medardo para sua espelunca, medicando-o e salvando-o. Foi a partir de uma espécie de ritos milagrosos que essa metade foi salva. Estamos na ambiguidade do gênero fantástico, isto é, nessa obra há uma fratura da realidade, e a incerteza entre os acontecimentos serem reais ou sobrenaturais é a base de sua criação. Uma meia parte foi salva pela patrulha do exército, sendo remendada e costurada; enquanto a outra metade foi tratada e medicada por eremitas. Quando esta meia parte de Medardo volta para Terralba, os moradores não a viu chegando nem entrando em seu castelo. Por isso, primeiro aparecia a metade má e, em seguida, a boa, o que gerou uma certa confusão na mente dos outros personagens da obra, pois não entendiam atitudes tão opostas do mesmo visconde.

Mas começavam a chegar notícias de várias fontes sobre uma natureza dupla de Medardo. [...] Fazia tempo que a besta do visconde só golpeava as andorinhas; e não para matá-las, mas para feri-las e aleijá-las. Contudo, agora podiam ser vistas no céu andorinhas com as patas enfaixadas e amarradas com gravetos de apoio ou com as asas coladas e com curativos; havia um bando de andorinhas assim ataviadas que voavam

\footnotetext{
4 Todorov (2004) sugere que o texto constrói o insólito, mas a adesão ao fantástico puro, maravilhoso ou estranho estaria nas mãos do leitor. Para ele, a "hesitação" produz o gênero fantástico na narrativa, pois o leitor, frente a algo que esteja no plano do desconhecido, hesitará entre uma explicação lógica e outra sobrenatural para os acontecimentos evocados.
} 


\section{Revista do SELL}

v. 6 , no. 2

ISSN: $1983-3873$

com prudência todas juntas, feito convalescentes de um hospital de passarinhos, e inverossimilmente dizia-se que o próprio Medardo era o médico (CALVINO, 2011, p. 67, 68).

As pessoas estavam confusas sobre a natureza "dupla" do visconde. Enquanto a metade má golpeava as andorinhas para machucá-las, a outra metade fazia o contrário, ajudava os passarinhos a se recuperarem, como numa espécie de veterinário. Assim, quando as pessoas viam as andorinhas sendo golpeadas e depois portando curativos, elas não acreditavam que o próprio visconde era quem golpeava e socorria ao mesmo tempo. Conforme à concepção individualista do sujeito da identidade lluminista, o Visconde tornou-se duas pessoas com identidades opostas: uma má e outra boa.

Crianças perdidas no bosque, cheias de medo, eram abordadas pelo homem de muleta, que as conduzia para casa pela mão e Ihes oferecia figos e bolinhos fritos; viúvas pobres eram ajudadas por ele a carregar lenha; cães picados por cobras eram tratados, presentes misteriosos eram encontrados pelos pobres nos parapeitos e nos portais, árvores frutíferas arrancadas pelo vento eram replantadas e fixadas em seus canteiros antes que os proprietários pusessem o nariz fora da porta. Porém, ao mesmo tempo as parariçõies do visconde meio enrolado no manto negro assinalavam acontecimentos terríveis: crianças sequestradas eram encontradas prisioneiras em grutas obstruídas por pedras; avalanches de troncos e rochas rolavam em cima das velhotas; abóboras maduras eram despedaçadas por pura maldade (CALVINO, 2011, p. 68).

Uma metade era completamente bondosa, ajudava as crianças a voltarem para casa, dava-Ihes comida; ajudava no carregamento de lenhas; os animais machucados também eram socorridos e ajudados. Enfim, uma metade de visconde que fazia o bem para as pessoas, os animais e a natureza. Inversamente, a metade direita do visconde é extremamente maldosa: sequestrava crianças deixando-as em grutas obstruídas por pedras; rolava troncos e rochas em cima das velhas; desperdiçava abóboras maduras. Era uma metade que não se importava com o bem estar social, nem mesmo com a natureza, porque acabava destruindo o que lhe apetecia.

A identidade do Visconde transformou-se quando ele foi atingido pela bala de canhão. Antes ele era uma mistura de bondade com maldade, mas depois de ser separado ao meio sua identidade essencializou-se e ficou em extremos, ou seja, foi aí que ela passou a ser "unificada". Uma metade via a necessidade de ser má com as pessoas quando lhe desagradavam, e a outra gostava de ajudar as pessoas e impor modos de vida que. Sua identidade, portanto, que antes era uma mistura de vontades e virtudes, foi modificada já que ele passou a ter um mesmo corpo, porém separado no 


\section{Revista do SELL}

v. 6 , no. 2

ISSN: $1983-3873$

meio, cujas partes agiam de forma diferente (e essencializada) com as pessoas com quem conviviam.

De forma diferente, a noção de sujeito sociológico reflete a crescente complexidade do mundo moderno e a consciência de que o núcleo interior lluminista não era autônomo nem autossuficiente, mas formado "na relação com 'outras pessoas importantes para ele', que mediavam para o sujeito os valores, sentidos e símbolos - a cultura - dos mundos que ele/ela habitava" (HALL, 2006, p. 2). Essa concepção interativa da identidade e do eu é formada na interação entre o "eu" e a sociedade. "O sujeito ainda tem um núcleo ou essência interior que é o 'eu real', mas este é formado e modificado num diálogo contínuo com os mundos culturais 'exteriores'” e suas identidades (idem).

O Visconde decide se apaixonar por Pamela e nem ela consegue mediar valores, sentidos e símbolos, mas é ele o dono das escolhas.

O visconde disse consigo mesmo: "Acontece que entre meus sentimentos intensos não tenho nada que corresponda àquilo que os inteiros chamam de amor. E se para eles um sentimento tão idiota possui tanta importândia, o que para mim poderá corresponder a isso, certamente será magnífico e terrível". E decidiu apaixonar-se por Pamela (CALVINO, 2011, p. 51).

A metade má do visconde, afivelado na sela de seu cavalo saltador, estava cavalgando pelo vale quando viu Pamela em meio a um prado junto com suas cabras. Independentemente da vontade de Pamela, ela decidiu apaixonar-se e casar-se com ela. Pamela "é apenas um ideograma esquemático de concretude feminina em contraste com a desumanidade do partido ao meio" (CALVINO, 2014, p. 11). Nota-se que há interação entre ele e as pessoas com quem convive, mas ele é o suplente, o comandante, aquele de quem, possivelmente, sairia a influência na constituição de uma identidade. Por ser o assessor do rei, ele impõe às pessoas um modo de convívio, a forma como deve ser levado os negócios, comanda a justiça social. Quando ambas as partes do visconde marcam um duelo para ver quem se casaria com Pamela, elas acabam dando uma estocada na linha que interrompia seus corpos e, depois, são unidas novamente. Sua identidade, que era contraditória em si, acabou sendo unida em um mesmo espaço-corpo.

Para Thomas Hobbes, citado por Limongi (2007, p. 135), a origem das sociedades deve ser reputada pelo medo recíproco, e não pela boa vontade recíproca dos homens. Esses se associam por medo, o qual "dá sustentação às relações contratuais em que consistem os vínculos civis". O Visconde ocupa um lugar de controle sobre as pessoas com quem convive. Medo que sustenta seus vínculos civis e que impõe o 


\section{Revista do SELL}

v. 6 , no. 2

ISSN: $1983-3873$

cumprimento de suas vontades, que valida os contratos sociais. Por assumir o papel de assessor do rei na ausência do titular, ele comanda seus territórios e as vilas próximas ao seu castelo, impõe a moral e manda pessoas para prisão e para forca quando the desagradam. Assim, verifica-se o medo associado aos vínculos sociais e percebe-se que há relações de poder que comandam nossas reações, nossas construções identitárias e nossa vida social e psíquica. Os outros personagens da obra de Calvino experimentavam o medo do visconde e reagiam de forma a evitar encontrá-lo, por exemplo:

fazia de tudo para evitar meu tio e para nem sequer ouvir falar dele. Quando Ihe falavam do visconde e de sua crueldade, o dr. Trelawney sacudia a cabeça e enrugava os lábios murmurando: 'Oh, oh, oh!... Sst, sst, sst!', como quando lhe contavam uma história incoveniente (CALVINO, 2011, p. 33).

Diante do perigo, de uma situação de insegurança, tendemos ao sentimento do medo. As pessoas tinham medo de, sequer, encontrar com 0 visconde, independentemente de ser a parte boa ou má. Somos perseguidos pelo medo, seja o medo universal da morte, o provocado pelo caos do meio ambiente, pelas novas tecnologias e armas nucleares, ou mesmo o medo daquilo que não podemos ver nem tocar, como fantasmas e assombrações, que de alguma forma chegaram até nós como criaturas sobrenaturais ofensivas (ou não), mas desconhecidas e, por isso, provocadoras de medo. Para Bauman (2008, p. 8), medo é o nome que damos à nossa incerteza, nossa ignorância da ameaça e do que deve ser feito, do que pode e do que não pode, para fazêla parar ou enfrentá-la, se destruí-la não estiver ao nosso alcance. Para o autor, o medo é "mais assustador quando difuso, disperso, indistinto, desvinculado, desancorado, flutuante, sem endereço nem motivo claros; quando nos assombra sem que haja uma explicação visível" (idem), quando a ameaça que tememos pode ser vislumbrada, mas não podemos vê-la. Febvre, citado por Bauman (2008), vinculava a ubiquidade do medo à escuridão, pois nela tudo pode acontecer, o que virá é imprevisível e é onde habita a incerteza, o medo.

Ele é um "sentimento vital que nos protege dos riscos da morte. Mas em razão dele desenvolvemos o sentido da curiosidade e a disposição à coragem, que superam a mera função de defesa da sobrevivência, pois possibilitam a expansão das pulsões de vida" (KEHL, 2007, p. 89). O medo é um sentimento estimulante e suas fontes são misteriosas. Ele incentiva a criatividade e o desejo do conhecimento uma vez que "permite, de um lado, sair da ignorância do perigo e evitar a imprudência; e, por outro 


\section{Revista do SELL}

v. 6 , no. 2

ISSN: $1983-3873$

lado, à medida que nos mobiliza para a ação, permite evitar a covardia" (FROGNEUX, 2007, p. 188), e pode nos levar a usar nossos conhecimentos e criatividade para algo desconhecido. Desse modo, diante de seres extraordinários como o visconde, os outros personagens e nós, leitores, reagimos perplexos, surpresos e reflexivos.

As cabras observavam o visconde com seu olhar fixo e inexpressivo, cada uma em posição diferente mas todas juntas, com os dorsos arrumados num estranho desenho de ângulos retos. Os porcos, mais sensíveis e ágeis, grunhiram e saíram correndo dando-se barrigadas, e então nem nós pudemos mais esconder nosso espanto (CALVINO, 2011, p. 23).

Os personagens da obra, bem como os porcos, acabaram sentindo espanto ao ver a metade de Medardo pela primeira vez. Porém, depois logo se acostumaram com aquela figura exígua e continuaram a vida como se nada tivesse acontecido com ele. $\mathrm{O}$ espaço-corpo dele atrai nosso interesse à medida que é um humano de outra espécie no contexto textual, ele quebra com nossa realidade. A partir do espaço de seu corpo pensamos em nossa finitude natural ou podemos refletir sobre aquilo que ameaça nossa integridade física e humana. Ademais, Calvino não tinha o propósito de defender uma poética contra outra, nem mesmo intenções de alegoria moralista ou política. Ele se ressentia da atmosfera daqueles anos de escrita da obra: "Estávamos no auge da guerra fria, havia uma tensão no ar, um dilaceramento surdo, que não se manifestavam em imagens visíveis mas dominavam os nossos ânimos" (CALVINO, 2014, p. 9). Aconteceu que ao escrever essa história fantástica, acabou "exprimindo não só o sofrimento daquele período particular como também o impulso para sair dele" (idem). O autor não aceitava passivamente a realidade negativa, difícil, e ainda desejava inserir nela o movimento, "a fanfarronice, a crueza, a economia de estilo, o otimismo imbatível que tinham sido marcas da literatura da Resistência" (ibidem). O que Ihe interessava era um homem partido ao meio, "mutilado, incompleto, inimigo de si mesmo é o homem contemporâneo. Marx chamou-o de 'alienado', Freud preferiu 'reprimido'; um estado de harmonia antiga perdeuse, aspira-se a uma nova completude" (CALVINO, 2014, p. 10).

Para Roas (2001, p. 30), a transgressão que provoca o fantástico, a ameaça que supõe para a estabilidade de nosso mundo, gera uma impressão terrorífica tanto nos personagens como no leitor. Não é um medo físico nem a intenção de provocar um susto no leitor ao final da história, mas uma inquietação, uma reação de inquietude experimentada tanto pelos personagens como pelo leitor, ante a possibilidade efetiva do sobrenatural e a ideia de que o irreal pode irromper no real. $O$ visconde é um fanfarrão, 


\section{Revista do SELL}

v. 6 , no. 2

ISSN: $1983-3873$

uma figura grotesca e cômica que provoca esse medo proposto por Roas, pois podemos sentir uma impressão de terror, uma inquietação, uma angústia diante dessa figura que tem a possibilidade de existência no real, e que mostra o irreal em meio à realidade.

À vista disso, nota-se que a identidade e o medo fazem com que os sujeitos se adaptem à estrutura social. Isso cria a ilusão de estabilidade dos sujeitos e dos mundos culturais que eles habitam, "tornando ambos reciprocamente mais unificados e predizíveis" (HALL, 2006, p. 2). Em nossa realidade cotidiana, o sujeito que possivelmente era constituído de uma identidade unificada e estável sempre foi e está se tornando cada vez mais fragmentado, composto não de uma, mas de várias identidades. Para Hall (2006, p. 2), as identidades que compunham a sociedade e asseguravam nossa subjetividade com as necessidades objetivas da cultura, estão "entrando em colapso, como resultado de mudanças estruturais e institucionais. O próprio processo de identificação, através do qual nos projetamos em nossas identidades culturais, tornou-se mais provisório, variável e problemático" (idem). Os sujeitos se adaptam à sociedade e à cultura em um processo constante de modificações.

Assim como o Visconde, há em nós identidades contraditórias e, por isso, "nossas identificações estão sendo continuamente deslocadas, em função de elementos nacionais, culturais, de gênero, de classe social, de posição política e religiosa, enfim, das várias identificações que formam o sujeito" "rizomático" de nossa época (FIGUEIREDO, 2015, p. 191). O sujeito pós-moderno é concebido "como não tendo uma identidade fixa, essencial ou permanente. A identidade torna-se uma 'celebração móvel': formada, transformada continuamente em relação às formas pelas quais somos representados ou interpelados" pelos sistemas culturais que nos rodeiam (HALL, 2006, p. 2). Como máscaras, os sujeitos assumem identidades diferentes em variados momentos, um espaço liso e adaptável. Somos confrontados por várias identidades o tempo todo, dentre as quais parece possível fazer escolhas.

Quanto mais a vida social se torna mediada pelo mercado global de estilos, lugares e imagens, pelas viagens internacionais, pelas imagens da mídia e pelos sistemas de comunicação globalmente interligados, mais as identidades se tornam desvinculadas - desalojadas - de tempos, lugares, histórias e tradições específicos e parecem "flutuar livremente" (idem, grifo do autor).

Assim como o Visconde, o sujeito pós-moderno é constituído de identidades que vão para diferentes direções: "Eram dois pretendentes partidos ao meio que, tomados 


\section{Revista do SELL}

v. 6 , no. 2

ISSN: $1983-3873$

pela excitação da véspera, erravam pelas quebradas e precipícios do bosque, envoltos nos mantos negros, um no magro cavalo e o outro na mula meio esfolada" (CALVINO, 2011, p. 90). O movimento do personagem não é simétrico: uma parte mostra sua personalidade nas plantas e nos animais, por exemplo, quando os parte ao meio. É um espaço que fala sobre ele. A outra metade é reconhecida quando prega a moral e dá presentes aos pobres, por exemplo. Tanto a identidade do visconde como a de qualquer indivíduo se dá por heterotopia, pela diferença com o outro, pela alteridade. Se "sentimos que temos uma identidade unificada desde o nascimento até a morte é apenas porque construímos uma cômoda estória sobre nós mesmos ou uma confortadora 'narrativa do eu"' (HALL, 2006, p. 3). A identidade totalmente "unificada, completa, segura e coerente é uma fantasia. Ao invés disso, à medida em que os sistemas de significação e representação cultural se multiplicam, somos confrontados" por uma multiplicidade cambiante de identidades possíveis (idem), com as quais poderíamos nos identificar.

Para Hall (2006, p. 3), outro aspecto da questão da identidade está relacionado ao processo de mudança conhecido como "globalização". As sociedades modernas estão em constantes mudanças rápidas e permanentes. Não é apenas a "experiência de convivência com a mudança rápida, abrangente e contínua, mas é uma forma altamente reflexiva de vida", na qual, para Giddens (apud HALL, 2006, p. 3), "as práticas sociais são constantemente examinadas e reformadas à luz das informações recebidas sobre aquelas próprias práticas, alterando, assim, constitutivamente, seu caráter". A sociedade, assim como o visconde, não é um todo unificado e bem delimitado, é sempre deslocada. Laclau, citado por Hall (2006, p. 4), ressalta que as sociedades são caracterizadas pela diferença. Portanto, a identidade é construída a partir e pela alteridade. O Visconde era reconhecido pela diferença de atitudes que tinha: quando aparecia uma metade que cortava rãs, que colocava fogo nos celeiros, era a má; quando aparecia uma parte que ajudava as pessoas e os animais, era a boa. Ele era reconhecido pela diferença de atitudes de bem e mal.

Outrossim, as sociedades são "atravessadas por diferentes divisões e antagonismos sociais que produzem uma variedade de diferentes 'posições de sujeito' isto é, identidades - para os indivíduos" (LACLAU apud HALL 2006, p. 4). Se elas não se desintegram totalmente não é por serem unificadas, "mas porque seus diferentes elementos e identidades podem, sob certas circunstâncias, ser conjuntamente articulados" (idem). Entretanto, essa articulação é parcial e a estrutura da identidade conserva-se aberta. Essa concepção de identidade, diferente das outras supracitadas, é a 


\section{Revista do SELL}

v. 6 , no. 2

ISSN: $1983-3873$

que mais se aproxima da identidade e da configuração corpórea do protagonista de Calvino, dado que ele representa a própria fragmentação da identidade por ter seu corpo e sua forma de ser divididas ao meio. Ele mostra uma desarticulação das identidades estáveis do passado, e aponta a possibilidade de novas articulações identitárias.

Antes o sujeito era visto como unificado e possuidor de uma identidade estável, mas à medida que as sociedades foram se tornando mais complexas, surgiu uma concepção mais social do sujeito, o qual "passou a ser visto como mais localizado e 'definido' no interior dessas grandes estruturas e formações sustentadoras da sociedade moderna" (HALL, 2006, p. 7). Conquanto, em meio à pluralidade de identidades formadoras de indivíduos, ele se encontra "isolado, exilado ou alienado, colocado contra o pano-de-fundo da multidão ou da metrópole anônima e impessoal" (idem), mas que, ao mesmo tempo, sendo composto por uma singularidade, ele é distintivo e único e, por isso, compõe e promove a articulação e convivência de novas identidades. O Visconde não passou a ter novas identidades, mas a sua identidade foi fragmentada, partida, deslocada, quando ele foi dividido ao meio. Antes de ser separado ao meio, ele possuía suas identidades "unificadas", de bem e mal, ele era considerado "inteiro" por possuir seu arbítrio em um corpo não separado em dois. No entanto, ao ser partido ele passou a ter seu espaço-corpo e seus comportamentos opostos. A partir disso, lemos que as identidades não são puras, mas constituídas por mais de um elemento e sempre em constante construção.

\section{Considerações finais}

Entendemos que os questionamentos sobre a questão da identidade vêm sendo estudados desde uma certa concepção de identidade do fim do século XVIII, a qual era vista como uma identidade individualizada, particular, autêntica e unificada. Esse ideal corresponderia ao que Hall (2006) denominou de identidade do sujeito do lluminismo. Em seguida surgiu a concepção de identidade do sujeito sociológico, a qual, segundo Figueiredo (2015), está na origem do nacionalismo moderno ligada ao reconhecimento e dialogismo para com as variadas culturas. Nela o indivíduo é visto como não autossuficiente e formado na relação com os outros. Na "nossa percepção do outro prima a pessoa social, moral, psicológica - e não o puro existente humano que ele é" (GIL, 2009, p. 20). É na alteridade que nos reconhecemos como possuidores de identidades múltiplas e dispersas. 


\section{Revista do SELL}

v. 6 , no. 2

ISSN: $1983-3873$

Vimos que na segunda metade do século XX surge a concepção de identidade do sujeito pós-moderno, fragmentado. Por isso, propusemos relacionar essa identidade pósmoderna, não fixa, essencial ou permanente, com o protagonista da obra $O$ visconde partido ao meio, de Italo Calvino. Seu espaço-corpo não era fixo, mas transformou-se ao ser atingido por uma bala de canhão e depois foi unido novamente. Antes de ser partido ao meio, Medardo possuía suas identidades "unificadas", de bem e mal, porém, ao ser dividido cada uma delas ficou em uma parte de seu corpo. Isto mostra, por exemplo, que somos constituídos por dicotomias, por comportamentos diferentes e até opostos. "A única maneira de remover o obstáculo da identidade é destruí-la como instância territorializante" (GIL, 2009, p. 20). As identidades não são puras, podemos escolher várias para nossa constituição como sujeitos. Assim, o conhecimento e o acesso à informação são importantes para a formação cultural e identitária de uma pessoa.

O debate sobre a questão da identidade cultural na pós-modernidade ainda é bastante complexo e fluido, sem contornos definidos. Entretanto, hoje se fala de identidades plurais, fragmentadas, "ou, ainda, de identificações, que teria o caráter provisório porque em constante devir" (FIGUEIREDO, 2015, p. 189). Assim, a identidade estaria vinculada à ideia de reconhecimento e diálogo. Analogamente ao Visconde, notamos que sua identidade passou a ser uma dicotomia entre bem e mal contendo um ponto comum: suas metades se tornaram desagradáveis no meio em que viviam.

$\mathrm{Na}$ obra de Calvino, a literatura fantástica pode propiciar uma leitura da sociedade, pois a leitura pode revelar metaforicamente as práticas ideológicas do mundo real através da ficção, e o Visconde mostra o quanto as pessoas podem se tornar apáticas diante da maldade e igualmente atemorizadas diante da bondade; faz-nos pensar naquilo que ameaça nossa integridade física e humana; mostra que o ser humano é sociável quando nutrido de suas identidades; que quando os sujeitos estão diante de personalidades extremas eles ficam desorientados. Além disso, o ser humano nunca se sente completo, está sempre pela metade, vazio, como se algo the faltasse.

Enfim, verificamos que ao decidir se apaixonar por Pamela, as metades de Medardo, depois do duelo, foram unidas novamente: "E Pamela exclamou: - Finalmente terei um marido com todos os seus atributos" (CALVINO, 2011, p. 94). A partir desta fala, inferimos que somos constituídos humanamente a partir de elementos díspares e dispersos com os quais temos contato, mas não nos é inerente e, sim, que nos integram a partir de nossas escolhas e identificação que fazemos ao longo de nossa vida, a partir de 


\section{Revista do SELL \\ v. 6 , no. 2 \\ ISSN: $1983-3873$}

nossas vivências. Há um condicionamento do nosso modo de vida, das nossas emoções e dos nossos comportamentos à dinâmica social. O que acreditamos ter como parte de nossa identidade está intrinsicamente relacionado à sociedade em que vivemos. Como versa Achugar (1994, p. 19), toda biblioteca, por estar em ruínas, anuncia uma ou múltiplas bibliotecas em construções. Não obstante, também vemos a identidade assim: por não ser fixa nem unificada, encontra-se sempre em dispersão, em mudança, em construção, anunciando a constituição/construção de um sujeito misto de identidades.

\section{Referências}

ACHUGAR, Hugo. La biblioteca en ruínas. Reflexiones culturales desde la periferia. Montevideo: Ediciones Trilce, 1994, p. 13-25.

BAUMAN, Zygmunt. Medo líquido. Tradução de Carlos Alberto Medeiros. Rio de Janeiro: Jorge Zahar Ed., 2008.

CALVINO, Italo. Assunto encerrado: discurso sobre literatura e sociedade. Tradução de Roberta Barni. São Paulo: Companhia das Letras, 2006.

CALVINO, Italo. O Visconde Partido ao Meio. Tradução de Nilson Moulin. São Paulo: Companhia das Letras, 2011.

CALVINO, Italo. Os nossos antepassados. Tradução de Nilson Moulin. São Paulo: Companhia de Bolso, 2014.

COVIZZI, Lenira Marques. O insólito em Guimarães Rosa e Borges. São Paulo: Editora Ática, 1978.

FIGUEIREDO, Eurídice. Identidade nacional e identidade cultural. S.L. S.D. p. 189-205. Disponível em:

<file:///C:/Users/Helen/Downloads/Identidade\%20nacional\%20e\%20identidade\%20cultural \%20(1).pdf $>$. Acesso em: 07/2015.

FURTADO, Filipe. A construção do fantástico na narrativa. Lisboa: Livros Horizonte, 1980.

FURTADO, Filipe. Fantástico (modo). E-dicionário de termos literários de Carlos Ceia.

Disponível em: <http://www.edtl.com.pt/index.php?opition=commtree\&link id=188\&ltemid=2>. Acesso em: 07/2015.

FROGNEUX, Nathalie. O medo como virtude de substituição. In: NOVAES, Adauto (Org.). Ensaios sobre o medo. Tradução de Marcelo Gomes. São Paulo: Editora Senac São Paulo: Edições Sesc SP, 2007.

GIL, José. Em busca da identidade - o desnorte. Lisboa: Relógio D’Água, 2009. 
HALL, Stuart. A identidade cultural na pós-modernidade. Tradução de Tomaz Tadeu da Silva e Guacira Lopes Louro. Rio de Janeiro: DP\&A Editora, 1a ed. 1992, 11a ed. 2006, 102 páginas. Disponível em:

<http://www.germe.net.br/uniesp/textos/seminarios/Freud/IDENTIDADE-POSMODERNIDADE.pdf>. Acesso em: 07/2015.

KEHL, Maria Rita. Elogio do medo. In: . NOVAES, Adauto (Org.). Ensaios sobre o medo. Tradução de Marcelo Gomes. São Paulo: Editora Senac São Paulo: Edições Sesc SP, 2007.

LIMONGI, Maria Isabel. A racionalização do medo na política. In: NOVAES, Adauto (Org.). Ensaios sobre o medo. Tradução de Marcelo Gomes. São Paulo: Editora Senac São Paulo: Edições Sesc SP, 2007.

ROAS, David (Org.). Teorías de lo fantástico. Madrid: Arco/Libros, 2001.

TODOROV, Tzvetan. Introdução à literatura fantástica. Tradução de Maria Clara Correa Castello. 3. ed. São Paulo: Perspectiva, 2004. 